\title{
PENERAPAN PASAL 56 KUHAP TENTANG BANTUAN HUKUM DI TIAP TINGKAT PEMERIKSAAN TERSANGKA (Studi Kasus Pada Penyidikan Polres Metro Tangerang Kota)
}

\author{
Dwi Saleha \\ Imran Bukhari Razif \\ dwisaleha07@gmail.com \\ imranrazif@gmail.com
}

Fakultas Hukum Universitas Muhammadiyah Tangerang

\begin{abstract}
ABSTRAK
Bantuan hukum yang berjudul penerapan pasal 56 KUHAP tentang bantuan hukum ditiap tingkat pemeriksaan tersangka (studi kasus pada penyidikan Polres Metro Tangerang Kota). Dengan rumusan masalah bagaimana penerapan pasal 56 KUHAP tentang bantuan hukum pada tingkat pemeriksaan di Polres Metro Tangerang Kota serta menganalisis upaya Polres Metro Tangerang Kota dalam sosialisasi pasal 56 KUHAP kepada masyarakat kurang mampu. pendekatan metode penelitian dilakukan secara normatif empiris dengan subjek penelitian direskrimum Polres Metro Tangerang Kota dan ketua Pusat Bantuan Hukum Peradi Tangerang, bantuan hukum merupakan suatu hak yang harus diperoleh tersangka sebagai suatu implementasi Negara hukum untuk menjamin hak asasi warga negaranya dalam mencapai suatu keadilan dan bantuan hukum merupakan hal fundamental yang harus di dapatkan oleh tersangka melihat banyak nya realitas ketimpangan hukum bagi seorang tersangka utnuk mendapatkan haknya. Bantuan hukum di upayakan secara optimal dibuktikan dengan adanya penurunan jumlah jenis tindak pidana pada periode tahun 2016 sampai 2018 yang terdiri dari 10 jenis tindak pidana, upaya Polres Metro Tangerang Kota dalam penerapan dan sosialisasi nya dengan memberikan informasi kepada tersangka, keluarga tersangka dengan cara mengedukasi pentingnya bantuan hukum pada tingkat pemeriksaan tersangka serta upaya pemberian papan informasi tentang hak tersangka yang wajib untuk mendapatkan bantuan hukum di tingkat kepolisian sehingga dalam pelaksanaannya bisa berjalan dengan baik untuk mencapai suatu keadilan.
\end{abstract}

Kata kunci: Bantuan Hukum, penerapan, Jenis tindak pidana.

\section{ABSTRACT}

Legal aid entitled the application of article 56 of the Criminal Procedure Code on legal assistance at each level of examination of suspects (case study in the investigation of Tangerang City Police Resort). With the formulation of the problem of how the application of article 56 of the Criminal Procedure Code on legal assistance at the level of inspection in the Tangerang City Metro Police as well as analyzing the efforts of the Jakarta Metro City Police in the socialization of article 56

Criminal Procedure Code to underprivileged people. approach to the research method is carried out empirically normatively with research subjects reskrimum Tangerang City Police Precinct and chairman of the Peradi Tangerang Legal Aid Center, legal aid is a right that must be obtained by the suspect as an implementation of the rule of law to guarantee the rights of its citizens in achieving justice and legal assistance is a fundamental thing that must be obtained by the suspect seeing the many reality of legal inequality for a suspect to get his rights. Legal assistance is optimally sought as evidenced by a decrease in the number of types of criminal acts in the period 2016 to 2018 consisting of 10 types of criminal acts, the efforts of the Metro Tangerang City Police in its application and outreach by providing information to suspects, suspects' families by educating the importance legal assistance at the suspect's investigation level and efforts to provide information boards about the rights of suspects who are required to obtain legal assistance at the police level so that in its implementation it can go well to achieve justice. 


\section{Pendahuluan}

Di dalam Kitab Undang-undang Hukum Acara Pidana (KUHAP) selain mengatur ketentuan tentang cara proses pidana juga mengatur tentang hak dan kewajiban seseorang yang terlibat proses pidana. M. Yahya Harahap berpendapat bahwa Kitab Undang-undang Hukum Acara Pidana telah mengangkat dan menempatkan seorang manusia dalam kedudukan yang bermartabat sebagai makhluk ciptaan Tuhan dalam hal ini menempatkan seorang manusia dalam posisi dan kedudukan yang harus diperlakukan dengan nilai-nilai luhur kemanusiaan (his entity and dignity as a human being) ${ }^{1}$.

Sistem peradilan pidana menyatakan bahwa seorang tersangka harus ditempatkan pada kedudukan manusia yang memiliki harkat dan martabat dan dinilai sebagai subyek bukan sebagai obyek tindak pidana. ${ }^{2}$ Sistem peradilan pidana mempunyai bagian pada tiap tahapan proses pidana diantaranya pada tahap awal pemeriksaan tersangka (interogasi) pada tingkat penyidikan.

Pada proses tahapan ini sangat penting sekali kita gali, mengingat bahwa banyak sekali tindak pidana yang terjadi salah satunya, peneliti meneliti diwilayah hukum Polres Metro Tangerang Kota dari kurun waktu tahun 2016 sampai awal 2019 yang terdiri dari 10 jenis kejahatan seperti (pembunuhan, penganiyaan, pencurian kebakaran, perjudian, peras, perkosaaan dan kenakalan remaja) yang terjadi diwilayah Polres Metro Tangerang Kota.

Bantuan hukum merupakan titik awal dalam pemeriksaan yang dapat digunakan oleh semua orang dalam rangka menuntut haknya atas adanya perlakuan yang tidak sesuai dengan kaedah hukum yang berlaku, hal ini didasari oleh arti pentingnya perlindungan hukum bagi setiap manusia sebagai subyek hukum guna menjamin adanya penegakan hukum. ${ }^{3}$

Bantuan hukum itu bersifat membela masyarakat terlepas dari latar belakang, etnisitas, asal usul, keturunan, warna kulit, ideologi, keyakinan politik, kaya miskin, agama, dan kelompok orang yang dibelanya. Keberadaan penasihat hukum dalam memberikan bantuan hukum pada tahap penyidikan diharapkan proses hukum menjadi adil bagi tersangka yang kurang mampu maupun yang tidak memahami hukum. Selain itu untuk memberikan kesempatan kepada masyarakat miskin untuk membela diri dengan didampingi pembelaan advokat yang profesional.

Dalam memberikan bantuan hukum pada tingkat penyidikan penasihat hukum mempunyai kedudukan yang penting dalam setiap sistem peradilan pidana, penasihat hukum (advokat) harus dapat bekerja sama dengan aparat penegak hukum lainnya

\footnotetext{
${ }^{1}$ Handayani Febri, Bantuan Hukum Di Indonesia, (Yogyakarta:Kalimedia), 2016, hlm. iii

2 M. Yahya Harahap, Pembahasan Permasalahan dan Penerapan KUHAP Penyidikan dan Penuntutan, Edisi Kedua, Cetakan Kesembilan, (Jakarta:Sinar Grafika), 2007, hlm.1-

${ }^{3}$ Winarta Frans Hendra, Bantuan Hukum Suatu Hak Asasi Manusia Bukan Belas Kasihan, (Jakarta:Elex Media Komputindo), 2000, hlm. 96
} 
seperti polisi, jaksa, dan pengadilan dalam mencapai tujuan, yaitu mencegah kejahatan, mencegah pengulangan kejahatan dan merehabilitasi pelaku kejahatan serta mengembalikan mereka ke masyarakat. Profesi advokat sebagai bagian dari bantuan hukum harus dapat menjalankan perannya dalam membela masyarakat kurang mampu dan tidak memahami hukum sama sekali yang biasanya menjadi obyek penyiksaan, perlakuan dan hukuman tidak adil, tidak manusiawi dan merendahkan martabat manusia.

Pemberian bantuan hukum ditingkat penyidikan dalam hukum acara peradilan pidana di Indonesia diharapkan mampu memberikan perlindungan maksimal terhadap hak-hak hidup tersangka, khususnya yang berasal golongan lemah dan miskin dalam bentuk bantuan hukum sejak tahap awal pemeriksaan terhadap tersangka, bantuan hukum tidak hanya dimaknai sebagai hak tersangka sejak tahap penyidikan, melainkan juga sebagai kewajiban yang harus dipenuhi oleh setiap aparat penegak hukum khususnya penyidik sebelum memulai pemeriksaan terhadap tersangka.

Perlindungan hak asasi tersangka sejak tahap penyidikan setidaknya diharapkan menjadi salah satu faktor yang meminimalisasi kemungkinan terjadinya kesewenangan oleh aparat penegak hukum maupun kemungkinan terjadinya penyimpangan dalam penerapan prosedur hukum acara pidana oleh karena nya pemeriksaan pada tingkat penyidikan merupakan hal yang penting untuk mendapatkan keadilan meminimalisir pelanggaran yang dapat terjadi pada tiap tingkatan yang meliputi intimidasi pada saat penyusunan Berita Acara Pemeriksaan (BAP) sehingga aparat penegak hukum tetap berpegang pada pedoman perilaku aparat penegak hukum dan nilai Hak Asasi Manusia (HAM). ${ }^{4}$

Berdasarkan latar belakang yang telah diuraikan maka dari itu penulis akan meneliti Bagaimana proses penerapan Pasal 56 Kitab Undang-Undang Hukum Acara Pidana (KUHAP) tentang bantuan hukum di tiap tingkat pemeriksaan tersangka (studi kasus pada penyidikan Polres Metro Tangerang Kota dan Bagaimana upaya Polres Metro Tangerang Kota dalam sosialisasi pasal 56 Kitab Undang-Undang Hukum Acara Pidana (KUHAP) kepada masyarakat yang kurang mampu.

Suatu penelitian yang dilakukan tentu harus mempunyai tujuan yang akan diperoleh dari sebuah hasil penelitian, Untuk mengetahui proses penerapan Pasal 56 Kitab Undang-Undang Hukum Pidana (KUHAP) tentang bantuan hukum ditiap tingkat pemeriksaan tersangka (Studi Kasus pada penyidikan Polres Metro Tangerang Kota dan Untuk mengetahui upaya Polres Metro Tangerang Kota dalam Penerapan sosialisasi Bantuan hukum yang terdapat di dalam pasal 56 kitab UndangUndang Hukum Pidana (KUHAP) kepada masyarakat.

\section{Metode Penelitian}

Penelitian merupakan Suatu kegiatan ilmiah yang metedeologinya mengandung makna yang lebih luas menyangkut prosedur dan cara melakukan verifikasi yang

\footnotetext{
${ }^{4}$ M. Yahya Harahap, Op. Cit, hlm. 11
} 
diperlukan untuk memecahkan atau menjawab masalah penelitian, oleh karena itu ketepatan menggunakan metode dalam penelitian adalah syarat utama dalam pengumpulan data, maka penulis mengadakan penelitian metode Jenis Penelitian ini dengan menggunakan pendekatan normatif empiris yaitu menganalisis permasalahan menurut ketentuan hukum dan peraturan yang berlaku sekarang dikaitkan dengan data empiris yaitu megambil data dilapangan yang berkaitan dengan pelaksanaan pasal 56 Kitab Undang-Undang Hukum Pidana (KUHAP) tentang bantuan hukum ditingkat pemeriksaan penyidikan (studi kasus Polres Metro Tangerang Kota). ${ }^{5}$

Dengan Jenis data yang dikumpulkan data primer adalah data yang diperoleh langsung dari Kitab Undang-Undang Hukum Acara Pidana yang terkait dengan penerapan pasal 56 Kitab Undang-Undang Hukum Pidana (KUHAP) Tentang bantuan hukum dan wawancara kepada penyidik di Polres Metro Tangerang Kota.

Dan Data sekunder adalah Data yang diperoleh dari literatur dan bahan hukum yang relevan dengan permasalahan dalam penyusunan skripsi. Data sekunder digunakan untuk melengkapi data primer apabila membutuhkan sumber data dari literatur dan bahan hukum yang berlaku. Adapun bahan yang lain seperti bahan hokum primer, bahan hokum sekunder dan bahan hokum tersier.

\section{Hasil Penelitian dan Analisis}

Penelitian penulis dilakukan dipolres Metro Tangerang Kota pada bulan November 2018, melalui Unit Reserse Kriminal Umum (Reskrimum) penelitian awal yang di lakukan penulis bertemu dengan salah satu sumber Operasional Reserse Kriminal Umum (Reskrimum) yaitu Bapak Inspektur Polisi Satu Budi Haryono beliau adalah salah satu penyidik Polres Metro Tangerang Kota.

Mulai dari sini penulis melakukan penelitian, di Operasional Reskrimum Polres Metro Tangerang Kota, penulis mendapatkan informasi awal untuk melakukan penelitian dari mulai kelengkapan pengecekan surat izin penelitian, serta mendapatkan arahan untuk melakukan penelitian dan mendapatkan dokumentasi data akhir jenis Tindak pidana.

Untuk selanjutnya diarahkan untuk menghadap Kepala Unit Reserse Kriminal Umum (Reskrimum) Polres Metro Tangerang Kota yaitu Bapak Sugiatno untuk meminta izin penelitian serta memaparkan tujuan penelitian untuk bahan skripsi dan selanjutnya diarahkan kepada Bapak Nur Ustad selaku kepala Sub Bagian Reserse Kriminal Umum (Reksrimum) Polres Metro Tangerang Kota.

Hasil wawancara dengan Kepala Sub Bagian Reserse Kriminal Umum (Reskrimum) Polres Metro Tangerang Kota. Penulis mendapatkan informasi mengenai penerapan bantuan hukum yang dilakukan oleh Unit Reskrimum dalam hal ini Bapak Nur Ustad mengatakan bahwa penerapan bantuan hukum yang dilakukan oleh penyidik unit Reserse Kriminal Umum (reskrimum) ini sudah dilakukan secara optimal.

\footnotetext{
${ }^{5}$ https://kbbi.web.id/empiris.html diakses pada tanggal 18 Mei 2019 pukul 20.30 wib.
} 
Namun dalam perjalananya Kepolisian Polres Metro Tangerang Kota unit Reserse Kriminal Umum mempunyai kendala salah satunya yaitu terdapat kesulitan mencari penasehat hukum (Advokat) yang dalam hal ini tidak semua penasehat hukum yang penyidik hubungi siap untuk mendampingi calon tersangka yang sedang di tangani, dan ada juga calon tersangka yang tidak mau mendapatkan bantuan hukum sama sekali, bukan berarti calon tersangka ini tidak mengerti atau buta hukum, akan tetapi ada juga si calon tersangka yang takut ketika mendapatkan bantuan hukum maka hukumannya akan ditambah dan diketahui tindakpidana yang sebenarnya.

Penyidik pun sangat menyadari hal itu dan selalu berusaha memberikan pelayanan yang terbaik kepada tersangka karena dalam hal ini tersangka juga mempunyai hak untuk mendapatkan bantuan hukum dan penyidik selalu memfasilitasi memberikan yang terbaik bagi tersangka dengan memberikan bantuan hukum melalui penasehat hukum selama si tersangka bersedia untuk dibantu dalam penangannnya.

Selain itu pula Bapak Nur Ustad juga memperkenalkan perihal proses tahapan pemeriksaan penyidikan yang dilakukan melalui adanya laporan polisi, surat perintah tugas, tugas surat penangkapan terhadap tersangka, surat perintah penyidikan, surat pemberitahuan dimulainya penyidikan, dan diajak langsung untuk melihat proses Berita Acara Pemeriksaan (BAP) tersangka, gelar perkara kasus tindak pidana, surat penunjukan penasehat hukum dan lain sebagainya.

Hasil Wawancara Dengan salah satu Tersangka, Setelah proses Berita Acara Pemeriksaan (BAP) tersangka, dilakukan penulis diberikan kesempatan untuk bertanya kepada salah satu tersangka yang kala itu mengenai kasus tindak pidana merk.

Salah satu tersangka yang berhasil di wawancarai setelah dilakukannnya Berita Acara Pemeriksaan (BAP) sebut saja tersangka dengan inisial "A", "A" menjelaskan bahwa perbuatan yang dilakukan perihal tindak pidana merk karena suruhan dari bos konveksi, tersangka juga mengatakan bahwa hanya menjadi kurir dari barang merk illegal yang distribusikan, bahkan tersangka tidak mengetahui bahwa barang yang distribusikan merupakan merk plagiat terkenal.

Tersangka hanya menjadi kurir suruhan dari perusahaan konveksi dan awal tersangka bekerja dikonveksi diajak oleh teman yang memproduksi barang itu, tersangka mengatakan kerjaannya hanya sebagai kurir bukan produksi, sebenarnya tersangka juga sempat bertanya kepada teman nya yang membuat merk itu dan kata teman nya pun berkata " kerjaan Lo hanya kurir nggak usah nanya merk produksi yang penting dapat uang untuk kehidupan sehari-hari” dan tersangka kaget ketika pada malam itu ada polisi yang beroperasi dan menangkap yang sedang bekerja di garmen, dan disini tersangka mulai menyadari bahwa barang yang selama ini tersangka bawa adalah barang yang produksi merk illegal.

Hasil wawancara dengan Ketua Pusat Bantuan Hukum PERADI Tangerang. Untuk memperkuat hasil penelitian yang dilakukan penulis pun mewawancarai salah satu narasumber Advokat yang dalam hal ini di sampaikan oleh Ketua Pusat Bantuan 
Hukum PERADI Tangerang yaitu Bapak Riza Hasbi, dalam wawancara yang penulis lakukan Bapak Riza Hasbi mengatakan bahwa pemberian bantuan hukum kepada tersangka harus dilakukan atau diberikan sebagai kewajiban serta pemenuhan hak tersangka.

Walaupun dalam hal ini Pusat Bantuan Hukum PERADI tidak atau belum bekerjasama dengan pihak kepolisian akan tetapi jika dimintakan untuk membantu pendampingan bantuan hukum maka Pusat Bantuan Hukum PERADI Tangerang siap untuk membantu karena seperti kita tahu bahwa bantuan hukum wajib diberikan oleh advokat dan sangat jelas ketika advokat disumpah.

Dalam hal ini pun kewajiban ini tertuang di dalam undang- undang Advokat No 18 tahun 2003, Peraturan Pemerintah No 83 tahun 2008 tentang tata cara pemberian bantuan hukum peraturan peradi No 1 Tahun 2010 tentang petunjuk pelaksanaan pemberian bantuan hukum.

Untuk mendapatkan bantuan hukum diposbakum Pengadilan Negeri Tangerang ini dalam hal teknis pelaksanaan secara prosedural Bantuan Hukum sangat mudah dilakukan cukup datang keposbakum Pengadilan Negeri Tangerang dan khusus Pusat Bantuan Hukum Peradi Tangerang pasti akan menerima kasus tersebut tanpa melihat status dan kedudukan orang tersebut dan jika terjadi penangkapan pada orang miskin maka posbakum Pengadilan Negeri Tangerang akan membantu masyarakat pencari keadilan.

Untuk posbakum Pengadilan Negeri Tangerang sendiri dalam menangani perkara pada semua tingkatan pidana dari penyidikan, persidangan tingkat I,II,dan Ke III Kasasi atau Peninjauan Kembali (PK) dan untuk kasus perdata juga pada semua tingkatan.

Merujuk kepada Pasal 56 KUHAP menurut nya sangat jelas bahwa wajib seorang tersangka untuk mendapatkan bantuan hukum dan dalam hal ini yang terdapat dalam Pasal 56 Kitab Undang-Undang Hukum Pidana (KUHAP) bukan pembatasan tetapi kewajiban pihak kepolisian, jaksa, dan hakim jika ancaman sebagaimana pasal tersebut maka orang yang disangkakan atau terdakwa wajib didampingi oleh Penasehat Hukum atau Advokat baik karena dia mampu ataupun tidak mampu.

Ketua Pusat Bantuan Hukum Peradi Pengadilan Negeri Tangerang mengatakan bahwa Bantuan hukum yang diberikan dalam penerapannya belum ideal karena belum menyebarnya informasi bantuan hukum dan gerakan Probono dimasyarakat dan karena masyarakat kurang untuk mendapatakan informasi tersebut.

Pembahasan penerapan 56 kuhap tentang bantuan hukum ditingkat penyidikan polres metro tangerang kota, bantuan hukum pada tingkat pemeriksaan penyidikan unit reskrimum sub II polres metro tangerang kota. Sesuai peraturan dalam Sistem Peradilan Pidana Indonesia sangat erat kaitannya dengan kepolisian dari mulai tahap penyidikan, penyelidikan, tingkat kejaksaan sampai dengan peradilan yang di jalankan di pengadilan. Tingkat kepolisian yang merupakan pintu Pertama dalam rangkaian sistem peradilan pidana, yang mempunyai peran penting dalam rangkaian penegakan hukum pidana di Indonesia. 
Peran penegakan hukum tidak terlepas dari ranah kepolisian. Kepolisian Negara Republik Indonesia merupakan aparat penegak hukum yang berinteraksi secara intensif dengan anggota masyarakat.

Di lain sisi berita yang beredar dimasyarakat bahwa penegakan hukum yang dilakukan oleh kepolisian masih tebang pilih. Hal ini pun yang sering di jumpai dalam hal penegakan hukum, seharusnya sebagai penegak hukum anggota Polri harus menjalankan tugasnya sebagai penegak hukum yang memberikan pelayanan kepada masyarakat.

Membangun penegakan hukum yang adil, bersih, dan bermanfaat bagi seluruh elemen masyarakat juga harus dimulai dari aparat penegak hukum Polri yang profesional, netral, bersih, baik, dan mandiri.

Tugas pokok Polri sebagai garda terdepan menjaga keamanan dan ketertiban masyarakat sekaligus sebagai pengayom, pelindung, dan pelayan masyarakat. Polri memiliki peran sentral untuk senantiasa bersentuhan dengan masyarakat, dalam hal ini upaya seorang Penyidik memegang peran penting dalam membangun kesan positif Polri di masyarakat.

Untuk itu Kepiawaian penyidik dalam menangani sebuah perkara pidana, penguasaan lapangan yang baik, penguasaan peraturan perundang-undangan yang baik, menemukan barang bukti yang nyata sebuah perkara pidana yang sedang ditangani, hingga menyerahkan seluruh berkas perkara dan tersangka kepada Jaksa Penuntut Umum (JPU) merupakan tugas besar dan membutuhkan pedoman.

Salah satu kewajiban penyidik yaitu memberikan bantuan hukum kepada tersangka dalam hal ini jelas terdapat dalam Peraturan KAPOLRI No 14 Tahun 2012 pasal 54 ayat 2 huruf F, dan dalam proses penerapannya pun diperkuat lagi dengan adanya Undang-Undang No 16 Tahun 2011 Tentang bantuan hukum.

Untuk memperkuat peraturan tersebut dilakukannya suatu penelitian yang berkaitan dengan penerapan pasal 56 KUHAP di Unit Reskrimum Polres Metro Tangerang Kota, tentang bantuan hukum yang diberikan oleh penyidik kepada tersangka pada tingkat pemeriksaan penyidikan, dalam tingkat pemeriksaan penyidikan, penyidik menekankan kepada prinsip penegakan hukum yang adil dibuktikan pada saat proses dilakukannya Berita Acara Pemeriksaan (BAP) tersangka yang dilakukan di Polres Metro Tangerang Kota.

Penerapan pasal 56 KUHAP di Unit Reskrimum Polres Metro Tangerang Kota, pada dasarnya merupakan hak tersangka yang harus dipenuhi sebagai suatu kewajiban bantuan hukum untuk memperoleh suatu keadilan melalui pendampingan hukum sampai perkaranya diproses di pengadilan. Selain itu bukan hanya pasal 56 KUHAP yang memperkuat tentang pemberian bantuan hukum tetapi di dalam pasal 114 KUHAP juga menguatkan untuk tersangka mendapatkan bantuan hukum.

Dalam tingkat penyidikan proses pemberian bantuan hukum yang dilakukan Polres Metro Tangerang Kota dari tingkat penyidikan di awali dengan adanya Pemeriksaan Tersangka, dalam hal ini Penyidik memiliki tugas wajib memberitahukan kepada tersangka mengenai hak menerima bantuan hukum sesuai 
dengan Pasal 114 KUHAP,dan penyidik pun bertanya kepada tersangka apakah sudah mempunyai penasehat hukum sendiri atau belum sehingga dalam hal ini memudahkan untu, mendaptakm keterangan tersangka untuk dibantu mendapatkan hak nya melalui bantuan hukum.

Tersangka yang menerima bantuan hukum harus memiliki surat keterangan miskin yang diperolehnya dari Kantor Kelurahan/ Kecamatan setempat sebelum memperoleh bantuan hukum, tersangka yang ingin diberi bantuan hukum harus memiliki syarat diantaranya, mengajukan permohonan secara tertulis untuk mendapatkan bantuan hukum yang berisi identitas pemohon dan uraian singkat mengenai pokok persoalan yang dimohonkan dan menyerahkan dokumen yang berkenaan dengan perkara, melampirkan surat keterangan miskin dari lurah, kepala desa untuk mendapatkan bantuan hukum apabila pemohon tidak mampu menyusun permohonan secara tertulis maka permohonan dapat diajukan secara lisan.

Setelah pemohon melengkapi surat tersebut selanjutnya penyediaan bantuan hukum yang dilakukan Penyidik Polres Metro Tangerang Kota menyediakan bantuan hukum yang sebelumnya penyidik belum bekerjasama dengan advokat atau organisasi bantuan hukum tetapi dalam hal ini penyidik menyadari bahwa tersangka harus mendapatkan hak nya untuk mendapatkan bantuan hukum maka penyidik pun akan membantu secara optimal dengan meyediakan penasehat hukum bagi tersangka.

Selanjutnya penasehat hukum melakukan komunikasi dengan tersangka tentang kasus yang ia hadapi kepada penasehat hukum untuk mendapatkan suatu keadilan hukum dan selanjutnya penasehat hukum melakukan Pendampingan hukum kepada tersangka karena bantuan hukum merupakan suatu hak maka oleh undangundang diwajibkan untuk didampingi oleh penasehat hukum. Ketentuan yang mengatur tersangka atau terdakwa yang wajib didampingi oleh penasihat hukum ini dapat dipahami dari ketentuan Pasal 56 ayat (1) KUHAP yang selengkapnya berbunyi : (1)Dalam hal tersangka atau terdakwa disangka atau didakwa melakukan tindak pidana yang diancam dengan pidana mati atau ancaman pidana lima belas tahun atau lebih atau bagi mereka yang tidak mampu yang diancam dengan pidana lima tahun atau lebih yang tidak mempunyai penasehat hukum sendiri, pejabat yang bersangkutan pada semua tingkat pemeriksaan dalam proses peradilan wajib menunjuk penasehat hukum bagi mereka. (2)Setiap penasehat hukum yang ditunjuk untuk bertindak sebagaimana dimaksud dalam ayat (1), memberikan bantuannya dengan cuma-cuma apabila ditarik kesimpulan dari ketentuan yang mengatur tersangka yang wajib didampingi penasihat hukum, diartikan bahwa, seorang tersangka atau terdakwa yang wajib didampingi penasihat hukum adalah tersangka yang di ancam dengan pidana mati, di ancam dengan pidana lima belas tahun atau lebih dan tersangka dengan kategori tidak mampu dan diancam dengan pidana lima tahun atau lebih. Yang dalam hal ini penyidik menawarkan bantuan hukum serta menyediakan bantuan hukum serta Pemberi bantuan hukum melakukan komunikasi dengan tersangka dan Tersangka didampingi dengan bantuan hukum.

Penyidik berkeyakinan ketika penegakan hukum dilakukan secara adil maka 
hukum dapat ditegakan dengan baik dan kepercayaan masyarakat terhadap hukum akan jauh lebih baik. Dalam tingkat pemeriksaan tersangka merupakan gerbang awal tersangka untuk mendapatkan keterangan akan status dugaan yang dia dapatkan ketika awal terjadinya penangkapan dengan dugaan melakukan tindak pidana. dan apabila pada tahap pemeriksaan tersangka dilakukan dengan baik maka akan terwujudnya penegakan hukum yang baik pula.

Bantuan hukum merupakan media yang bisa digunakan oleh semua orang untuk menuntut haknya atas adanya perbuatan yang tidak sesuai dengan kaedah hukum yang berlaku. Selain itu, dalam hal tersangka atau terdakwa yang disangka atau didakwa melakukan tindak pidana diancam dengan pidana mati atau ancaman pidana lima belas tahun atau lebih atau bagi mereka yang tidak mampu yang diancam dengan pidana lima tahun atau lebih yang tidak mempunyai penasihat hukum sendiri.

Penyidik menyatakan bantuan hukum harus di dapatkan pada tingkat pemeriksaan dan dalam proses peradilan wajib menunjuk penasihat hukum bagi mereka dan setiap penasihat hukum yang ditunjuk untuk bertindak memberikan bantuan hukumnya.

Menurut Soerjono Soekanto penegakan hukum harus dilakukan pada tingkat penyidikan melalui bantuan hukum, hal ini sangat vital sekali mengingat pentingnya penerapan bantuan hukum sebagai gerbang utama dengan tujuan untuk mencapai suatu keadilan, efektifitas bantuan hukum menurut soerjono soekanto dapat efektif apabila Faktor hukumnya sendiri dijalankan dengan baik ketika sudah ada peraturannya maka wajib seluruh elemen yang ada dalam undang-undang seperti aparat penegak hukum yang menjalankan dengan baik sehingga terwujudnya penegakan hukum yang efektif sehingga tersangka bisa mendapatkan haknya sesuai dengan peraturan yang telah ditentukan.

Faktor lain yang mempengaruhi efektivitas penegakan hukum yaitu sarana dan fasilitas ,dimana dengan adanya dukungan sarana atau fasilitas yang memadai,maka dengan mudah penegakan hukum berlangsung dengan baik, karena dengan dioptimalisasikan nya sumberdaya manusia yang mumpuni serta mempunyai karakter yang baik dan terampil, maka dengan mudah penegakan hukum dapat mencapai tujuannya, selain itu faktor terpenting ialah tenaga manusia yang berpendidikan tinggi dalam hal ini penegak hukum yang mempunyai kualitas yang mampu melayani dan mengayomi masyarakat sesuai dengan tugas dan bidangnya masing-masing, dan faktor selanjutnya ialah sarana informasi bantuan hukum yang harus digalakan secara massif dan berkesinambungan pada tiap sub bagian kantor kepolisian dalam hal ini Reserse Kriminal Umum Polres Metro Tangerang Kota sehingga masyarakat mendapatkan edukasi dan sosialisasi bantuan hukum yang disediakan oleh pihak kepolisian. ${ }^{6}$

Hal ini pun dipertegas kembali bahwa dalam hal seorang disangka melakukan

${ }^{6}$ Soerjono Soekanto, Faktor-Faktor Yang Mempengaruhi Penegakan hukum, (Jakarta :Rajawali Pers), 1983, hlm. 8. 
suatu tindak pidana sebelum dimulainya pemeriksaan oleh penyidik, penyidik wajib memberitahukan kepadanya tentang haknya untuk mendapatkan bantuan hukum atau bahwa ia dalam perkaranya itu wajib didampingi oleh penasihat hukum sebagaimana dimaksud dalam Pasal 56 KUHAP bahwa kemudian faktor -faktor yang telah di ungkapkan oleh soerjono soekanto dapat dierapkan dengan baik sehingga terwujudnya penegakan hukum yang berkeadilan.

Salah satu Penyidik Polres Metro Tangerang Kota pun nengatakan bahwa dalam Pasal 56 ayat 1 KUHAP dalam kata "wajib" merupakan sesuatu yang harus dijalankan oleh seluruh pejabat kepolisian pada semua tingkatan pemeriksaan dan secara optimal diupayakan dan di jalankan oleh para aparat penegak hukum, Terkhusus Reskrimum Polres Metro Tangerang Kota.

Agar para tersangka maupun terdakwa bisa optimal untuk mendapatkan haknya yaitu mendaptkan pemberian bantuan hukum dari penasehat hukum,yang dalam hal ini sebenarnya kepolisian belum bekerjasama dengan Pos Bantuan Hukum (POSBAKUM) ataupun penasehat hukum lain, hal ini pun yang menjadi kesulitan tersendiri bagi penyidik tetapi karena mengingat tugas dan kewajiban penyidik untuk memberikan bantuan hukum bagi tersangka maka penyidik berusaha untuk memberikan pelayanan yang baik dan mencari penasehat hukum yang siap untuk mendampingi tersangka dalam proses tahap tingkat pemeriksaan tersangka.

Dan apabila tersangka tidak mau untuk mendapatkan bantuan hukum yang diberikan oleh penyidik maka dari pihak penyidik pun menyediakan surat penolakan untuk mendapatkan bantuan hukum, dan penyidik pun mempersilahkan tersangka untuk memilih sendiri penasehat hukum nya untuk mendampinginya dalam tiap tahap proses pemeriksaan agar hak tersangka dalam hal ini bisa terpenuhi sehingga terwujudnya sistem penegakan hukum yang adil. Hak tersangka merupakan hak konstitusional sehingga sebelum dilakukan pemeriksaan pun si tersangka harus mempunyai penyadaran hak seperti, hak untuk tetap diam, hak untuk mengetahui bahwa setiap pernyataan akan dijadikan sebagai bukti, hak untuk di dampingi oleh penasehat hukum dan negara menyediakan penasehat hukum apabila tersangka memintanya.

Sehingga sudah seyogyanya penerapan bantuan hukum harus di terapkan secara optimal oleh para penyidik agar terwujudnya penegakan hukum yang professional sehingga hak tersangka pun bisa di dapatkan dengan baik sehingga terwujudnya suatu keadilan.

Upaya polres metro tangerang kota dalam sosialisasi pasal 56 kuhap kepada masyarakat kurang mampu. Bantuan hukum merupakan hal yang sangat esensial dalam menciptakan kehidupan yang adil serta melindungi hak asasi manusia. Kita tahu bahwa bantuan hukum yang diberikan bertujuan untuk melindungi hak-hak masyarakat dalam hal tersangkut masalah hukum dengan tujuan menghindari dari segala macam tindakan-tindakan yang dapat membahayakannya atau tindakan sewenang-wenang aparat penegak hukum. Keberadaan penasihat hukum dalam memberikan bantuan hukum pada tahap penyidikan diharapkan proses hukum 
menjadi adil bagi tersangka yang kurang mampu maupun yang tidak memahami hukum. Selain itu untuk memberikan kesempatan kepada masyarakat miskin untuk membela diri dengan didampingi pembelaan advokat yang profesional. Dalam memberikan bantuan hukum pada tingkat penyidikan penasihat hukum mempunyai kedudukan yang penting dalam setiap sistem peradilan pidana. Penasihat hukum (advokat) harus dapat bekerja sama dengan aparat penegak hukum Implementasi hak tersangka untuk memperoleh bantuan hukum pada tingkat penyidikan dapat dilihat dari sistem hukum itu sendiri. Tata cara pemberian bantuan hukum terhadap tersangka dapat dilihat dalam Pasal 54, Pasal 55, Pasal 56 KUHAP.

Berdasarkan hasil penelitian di lapangan, penyidik selalu menawarkan hak tersangka untuk di dampingi penasihat hukum, tetapi ada saja yang tersangka tidak menggunakan haknya tersebut, sehingga penyidik membuat berita acara yang ditandatangani tersangka dengan menunjukkan alasan tersangka tidak di dampingi penasihat hukum.

Upaya Polres Metro Tangerang Kota dalam sosialisasi kepada masyarakat mengenai bantuan hukum dengan cara memberikan informasi kepada tersangka, keluarga tersangka, ataupun masyarakat dengan cara mengedukasi dengan menekankan bahwa bantuan hukum itu wajib diberikan kepada seseorang selama dalam waktu dan pada setiap tingkat pemeriksaan, menurut tata cara yang ditentukan dalam Undang-undang ini”. Berdasarkan Pasal tersebut dapat diambil kesimpulan bahwa untuk membela hak-haknya, tersangka berhak untuk didampingi seorang atau lebih penasihat hukum pada setiap tingkat pemeriksaan. ${ }^{7}$

Sehingga bantuan hukum pada tingkat pemeriksaan merupakan suatu yang fundamental yang harus didapatkan oleh tersangka terkhusus masyarakat yang tidak mampu sehingga dalam hal ini pun bisa menghindarkan stigma negatif terhadap penyidik dalam melaksanakan tugas nya, agar terwujudnya penegakan hukum yang adil dan diharapkan masyarkat lebih cerdas lagi ketika sudah mendapatkan edukasi informasi yang diberikan penyidik kepada keluarga tersangka ataupun masyarakat yang berkaitan dan masyarakat pun diharapkan bisa berbagi informasi akan pentingnya bantuan hukum yang diberikan penyidik kepada seorang tersangka sehingga tersangka tidak kehilangan hak nya untuk mendapatkan bantuan hukum.

\section{Penutup}

\section{Kesimpulan}

a. Bantuan hukum merupakan hak fundamental yang harus ditegakan guna menciptakan kehidupan yang adil serta melindungi hak asasi manusia, karena bantuan hukum bertujuan untuk melindungi hak-hak masyarakat dalam hal tersangkut masalah hukum menghindari dari segala macam

\footnotetext{
${ }^{7}$ Zulaidi, Manfaat Pelaksanaan Bantuan Hukum Bagi Tersangka/ Terdakwa dalam Usaha Mencari Keadilan, (Bandung :PT. Refika Aditama,), 2010, hlm. 91
} 
tindakan-tindakan yang dapat membahayakannya atau tindakan sewenangwenang aparat penegak hukum.Bantuan hukum pada tingkat pemeriksaan tersangka pun yang dilakukan oleh Polres Metro Tangerang Kota di upayakan secara maksimal dengan dibuktikannya penerapan Bantuan hukum yang dilakukan oleh Polres Metro Tangerang Kota kepada tersangka hal ini bisa terlihat pada periode tahun 2018 sebanyak 52 kali, dengan 10 jenis tindak pidana pada Unit Reskrimum Polres Metro Tangerang Kota. Bantuan hukum merupakan suatu yang harus diberikan kepada tersangka secara utuh agar seorang tersangka bisa mendpatkan hak nya sesuai dengan peraturan yang telah ditetapkan sehingga terwujudnya penegakan hukum yang menciptakan kehidupan masyakarat yang seadil-adilnya.

b. Upaya Polres Metro Tangerang Kota dalam sosialisasi kepada masyarakat mengenai bantuan hukum dengan cara memberikan informasi kepada tersangka, keluarga tersangka, ataupun masyarakat dengan cara mengedukasi dengan menekankan bahwa bantuan hukum itu wajib diberikan kepada seseorang selama dalam waktu dan pada setiap tingkat pemeriksaan, menurut tata cara yang ditentukan dalam Undang-undang ini”. Berdasarkan Pasal tersebut dapat diambil kesimpulan bahwa untuk membela hak-haknya, tersangka berhak untuk didampingi seorang atau lebih penasihat hukum pada setiap tingkat pemeriksaan.

\section{Saran}

a. Kepada Polres Metro Tangerang Kota hendaknya dapat melakukan penyuluhan atau sosialisasi mengenai bantuan hukum semakin sering diadakan, agar masyarakat mengetahui pentingnya kedudukan bantuan hukum dalam menjamin hak tersangka pada setiap proses pemeriksaan tersangka serta melakukan kerjasama sosialisasi kepada pemerintah setempat, lembaga bantuan hukum, dan Penasehat hukum terkait pentingnya bantuan hukum bagi tersangka sehingga pelaksanaan bantuan hukum bisa lebih efektif dan terwujudnya penegakan hukum yang diharapkan bisa mencapai suatu keadilan.

b. Adanya sosialisasi papan informasi tentang hak tersangka yang wajib untuk mendapatkan bantuan hukum pada tiap tingkat pemeriksaan agar informasi tersebut bisa menjadi stimulus bagi orang yang membaca terkhusus masyarakat kota Tangerang dengan tujuan agar pada tahap pawal pemeriksaan hak tersangka bisa terpenuhi dengan baik sehingga terwujudnya penegakan hukum yang adil.

\section{Daftar Pustaka}

Ausaid, YLBHI, PSHK, IALDF, Panduan Bantuan Hukum di Indonesia, ( Jakarta: Sentralisme Production), 2007.

Effendi Tolib, Praktik Peradilan Pidana, (Malang: Setara Press), 2016. 
Fauzan Ahmad, Undang-Undang Lengkap Tentang Penegakan Hukum Advokat, Hakim, Jaksa Dan Polisi, ( Jakarta: PT Citra Aliya Bakti), 2004.

Frans Hendra Winarta, Bantuan Hukum di Indonesia, (PT Elex Media Komputindo: Jakarta), 2011.

Fuady, Munir, Hak Asasi Tersangka Pidana, (Jakarta: Kencana), 2015.

Handayani Febri, Bantuan Hukum Di Indonesia, (Yogyakarta: Kalimedia),2016.

Harahap Yahya, Pembahasan Permasalahan Dan Penerapan KUHAP, (Jakarta: Sinar Grafika), 2012.

Harahap Yahya, Pembahasan Permasalahan dan Penerapan KUHAP Penyidikan Dan Penuntutan, ( Jakarta: Sinar Grafika), 2014.

Hartono, Penyidikan dan Penegakan Hukum Pidana, (Jakarta: Sinar Grafika), 2010.

Hatta Moh, Beberapa Masalah Penegakan Hukum Pidana Umum Dan Pidana Khusus, (Yogyakarta: Liberty), 2009.

Kaligis,O.C, Perlindungan Hukum Atas Hak Asasi Tersangka, Terdakwa, dan Terpidana, (Alumni:Bandung), 2006.

Khoirin Nur, Peran Dan Fungsi Advokat Dan Lembaga Bantuan Hukum Di Indonesia, (Jakarta: Multimedia Grafika), 2015.

Marpaung Leden, Asas-teori-praktik Hukum Pidana, (Jakarta: Sinar Grafika), 2005.

Marpaung Leden, Proses Penanganan Perkara Pidana (Penyidikan Dan Penyelidikan), (Jakarta: Sinar Grafika), 2014.

Mukianto Jandi, Prinsip Dan Praktik Bantuan Hukum Di Indonesia, (Depok: Kencana), 2017.

Mulyadi Lilik, Hukum Acara Pidana Indonesia, ( Bandung: PT Citra Aditya Bakti), 2012.

Nawawi arief Barda, Masalah Penegakan Hukum dan kebijakan hukum pidana dalam penanggulangan kejahatan, (Jakarta:Prenadamedia Group),2018.

Purnama Adi, Transparansi Penyidik Polri Dalam Sistem Peradilan

Rukmini Mien, Perlindungan HAM Melalui Asas Praduga Tak Bersalah Dan Asas Persamaan Kedudukan Dalam Hukum, (Bandung:PT. Alumni), 2017.

Setiadi Edi, Sistem Peradilan Pidana Terpadu Dan Sistem Penegakan Hukum Di Indonesia, (Jakarta: Prenadamedia Group), 2017.

Sofyan Lubis, M, Prinsip “Miranda Rule” Hak Tersangka Sebelum Pemeriksaan: Jangan 
Sampai Anda Menjadi Korban Peradilan, (Penerbit Pustaka Yustisia:Yogyakarta), 2010.

Suroso Imam, Hukum Acara Pidana Karaktersitik Penghentian Penyidikan Dan Implikasi Hukumnya, (Yogyakarta: Laksbang PRESSindo), 2016.

Syahrin Alfi, Beberapa Masalah Hukum, (Jakarta: PT Sofmedia),2015. Widhayanti Erni, Hak-Hak Tersangka/Terdakwa Di Dalam KUHAP,

PP RI Nomor 83 Tahun 2008 Tentang Tata Cara Pemberian Bantuan Hukum CumaCuma.

Undang - Undang Negara Republik Indonesia Nomor 48 Tahun 2009 Tentang Kekuasaan Kehakiman.

Undang-Undang Dasar Negara Republik Indonesia Tahun 1945.

Undang-Undang Nomor 16 Tahun 2011 Tentang Bantuan Hukum.

Undang-Undang Republik Indonesia Nomor 18 Tahun 2003 Tentang Advokat.

Undang-Undang Republik Indonesia Nomor 18 Tahun 2011 Tentang Perubahan Atau. Undang-Undang No 22 Tahun 2004. Undang-Undang Republik Indonesia Nomor 2 Tentang Kepolisian.

https://megapolitan.kompas.com/read/2018/07/25/20124961/pendi-pembunuh-istri-dananak-di-tangerang-divonis-20-tahun-penjara diakses pada tanggal 1 Januari 2019 pada jam 09.20 wib.

www.negarahukum.com/hukum/bantuan-hukum.html diakses pada tanggal 23 januari 2019 pada pukul 15.00 wib

https://kbbi.web.id/empiris.html diakses pada tanggal 18 Mei 2019 pukul 20.30 wib.

https://id.m.wikipedia.org diakses pada tanggal 18 Mei 2019 pukul 20.30 wib.

http://www.definisimenurutparaahii.com/pengertian-studi-pustaka/diakses pada tanggal 19 Mei 2019 pukul 20.30 wib.

http://kokorafa76.blogspot.com/2012/informasi-studilapangan.html?m-1diakses pada tanggal 19 mei 2019.

Maxwell R Abbott. Right of access to criminal legal aid in Indonesia. Indonesia Law Review. Volume 8 number 1 january-April 2018. 